\title{
Relationship between polymorphisms in thrombophilic genes and preeclampsia In Egyptian population
}

\author{
Nahla A. Abdelaziz*, Amal H . Abu Saif**, Fawzia A. Alshishtawy * \\ Clinical Pathology*, Obstet \& Gynecol**,Alazhar University
}

\begin{abstract}
Background: Hypertensive disorders are a major cause of maternal and fetal death especially in developing nations. Preeclampsia has a familial component suggesting that one or more common alleles may act as susceptibility genes. Some families may have "private" predisposing mutations. Preeclampsia and its association with thrombophilia remain controversial, due to inconsistent results in different studies.

Aim: The aim of this study was to evaluate the relationship between thrombophilic genes mutations and preeclampsia in pregnant women in our region.

Methods: We compared 15 consecutive women with preeclampsia with 10 normal pregnant women. All women were tested for mutations of factor $\mathrm{V}$ lieden, Factor II (prothrombin gene ), Factor XIII, B fibrinogen, plasminogen activator inhibitor -1 4G/5G (PAI-1 4G/5G ), methylenetetrahydrofolate reductase (MTHR), angiotensin -converting enzyme (ACE) I/D , apolipoproteins (APO E and APO B ) genes. This study was based on reverse - hybridization technique using cardiovascular disease strip (CVD ) assay .

Results: PAI-1 4G/5G polymorphism was highly significantly increased in patient group as compared to control group $(60 \%$ versus $0 \%, \mathrm{p}=0.000)$. No significant differences were noticed as regards other thrombophilic genes in control and patient groups.

Conclusion We suggest that the pattern of PAI $4 \mathrm{G} / 5 \mathrm{G}$ polymorphism might represent a useful marker of increased risk of preeclampsia in our region. Also our findings suggest that women with severe complications of pregnancy should be tested for markers of thrombophilia.
\end{abstract}

Key words : Thrombophilic genes, Preeclampsia, Hybridization .

\section{Introduction}

Preeclampsia (PE) greatly contributes to maternal and fetal morbidity and mortality. Its cause is unknown, but its association with impaired placentation and activation of coagulative cascade has been demonstrated (1).

$\mathrm{PE}$ is a potentially serious condition which occurs in $2-7 \%$ of all pregnancies and can be life threatening for both the mother and child (2).

$\mathrm{PE}$ is also more common in women who have preexisting hypertension, diabetes, autoimmune diseases like lupus, various inherited thrombophilias like Factor $\mathrm{V}$ Leiden, or renal disease, in women with a family history of pre-eclampsia, obese women, and in women with a multiple gestation (twins, triplets, and more) (3).

The term thrombophilia is used to describe a heterogenous group of coagulation abnormalities (acquired or inherited) that are generally associated with increased risk of arterial and venous thrombosis (4).

Changes in blood coagulation and fibrinolysis during normal pregnancy induce a state of hypercoagulability, which predisposes to development of thrombosis. In combination with the physiological changes during pregnancy, hereditary thrombophilic defects may increase the risk of obstetric pathologies, including preeclampsia (5).

Inherited disorders of hemostasis and antiphospholipid syndrome have been postulated by prior investigators as common causes of thrombophilia. However, controversies have aroused about their actual mechanisms (6-7). The C677T polymorphism of the methylene tetrahydrofolate reductase (MTHFR) gene, the G20210A mutation of prothrombin gene (F II), the G1691A mutation of factor $\mathrm{V}$ 
Leiden (FV Leiden) and an insertion/ deletion polymorphism $(4 \mathrm{G} / 5 \mathrm{G})$ in the promoter of the plasminogen activator inhibitor type 1 (PAI-1) gene have been proposed as possible risk factors for preeclampsia (8).

The genetic factors related to the thrombophilias mentioned above appear to have different prevalence in the general population, and several studies are contradictory or failed to confirm a significant association with preeclampsia (9).

\section{Materials and methods}

\section{Preeclampsia group.}

15 pre-eclamptic patients admitted to Al-zahraa university hospital. They diagnosed as cases of preeclampsia according to the criteria proposed by American College of Obstetricians and Gynecologists ( 10 ). Preeclampsia was defined as the presence of hypertension associated with proteinuria after the 20th week of gestation in women known to be normotensive beforehand. Hypertension was defined as a blood pressure of at least $140 \mathrm{~mm} \mathrm{Hg}$ (systolic) and/or $90 \mathrm{~mm} \mathrm{Hg}$ (diastolic) on two occasions of up to 4-6 h apart. The blood pressure was measured on the right arm and with the patient always in the seated position. Proteinuria was defined as urinary excretion of $300 \mathrm{mg}$ or more of protein in $24 \mathrm{~h}$. The preeclampsia was classified as severe when there was a blood pressure $\geq 160 / 110 \mathrm{~mm} \mathrm{Hg}$; or urinary protein excretion $\geq 5 \mathrm{~g}$ per $24 \mathrm{~h}$; a platelet count of $<100,000 / \mathrm{cmm}$ in at least two samples; the combination of hemolysis, abnormal liver enzymes associated with persistent epigastric or upper right quadrant pain; persistent and severe symptoms as altered mental status, headaches, blurred vision or blindness; presence of multiorgan involvement such as pulmonary edema, oliguria $(<500 \mathrm{~mL}$ per day) according to previously published classifications (10). The body mass index (BMI) was calculated considering the values of weight and height obtained at the first appointment.

\section{Control group .}

The 10 control subjects with uncomplicated pregnancies among in and outpatients of the same hospital were enrolled during the same period of the study, and the inclusion criteria of the controls were: no rise in blood pressure, no hypertension or proteinuria, similar age $( \pm 2$ years), no biological relationship and a delivery date as close as possible to the delivery date(s) of the patient group and with a follow up for at least 3 months after delivery. All women who had chronic hypertension, renal disease, diabetes, collagen vascular diseases, cancer or thrombosis were not included in the study. All subjects participating in this study gave their written informed consent.

\section{Thrombophilic gene screening}

Peripheral blood was collecting on EDTA. The genomic DNA was isolated from $300 \mathrm{ml}$ of buffy coat using DNA purification kit.Biotinylated primers were used for PCR amplification. Finally the amplification products are selectively hybridized to The cardiovascular disease (CVD) test strip (Figure 1), which contains allele- specific (wild type and mutant) oligonuclotide probes immobilized as an array of parallel lines, CVD Strip Assay is based on the reverse - hybridization principle. Bound biotinylated sequences are detected using strptavidin - alkaline phosphate and color substrates.

The assay covers the following mutations : FV R506Q ( Leiden ), FV H 1299R ( R2) , Prothrombin G20210A, factor XIII V34L B- Fibrinogen - 455 G-A ,plasminogen activator inhibitor -1 ( PAI -1 ) 4G / 5G, methylenetetrahydrofolate reductase ( MTHFR) C677T , MTHFR A1298C , angiotensin -converting enzyme ( ACE) I/D , apolipoproteins B (Apo B ) R3500Q Apo E2 /E3 /E4 .

\section{Statistical analysis}

Student's t test was employed for comparison of the quantitative variables between the groups. Differences in proportions were tested by Fisher's Exact Test or $\chi 2$ test. Relative risks were estimated by the odds ratio and $p$ values of $<0.05$ were considered to be significant. All confidence intervals were calculated at the 95\% level and all statistical analyses were performed with SPSS software (version 10.0). 


\section{Results}

Table (1) shows the demographic and clinical characteristics of the cases and the controls. As expected, the mean gestational age at delivery was lower in cases than in controls, and the family history of preeclampsia was more frequent in patients. Obesity, defined by body mass index (BMI) $>30 \mathrm{~kg} / \mathrm{m} 2$ after adjustment for age, was prevalent in both groups being even more frequent in preeclamptic women. There were no significant differences in the parity and the smoking habits between patients and controls.

Table (2) shows the PAI-1 4G/5G polymorphism was highly significant increase in patient group as compared to control group (60\% versus
$0 \%, \mathrm{p}=0.0000)$. No significant differences have been noticed as regards other thrombophilic genes in preeclampsia. Therefore, we suggested that the pattern of PAI 4G/5G polymorphism might represent a useful marker of increased risk of preeclampsia in our region.

There were no significant differences in the prevalence of factor $\mathrm{V}$ leiden, factor XIII, M T H F E R (G 677T , A 129,8C), A C E I D , A P O B gene and A P O E gene.

When we compared severe preeclampsia $(n=6)$ with mild preeclampsia $(n=9)$ as regard interaction between more than one thrombophilic gene, we noticed increased prevelance of PAI-1 4G/5G gene in association with other thrombophilic genes interaction in severe preeclampsia group.

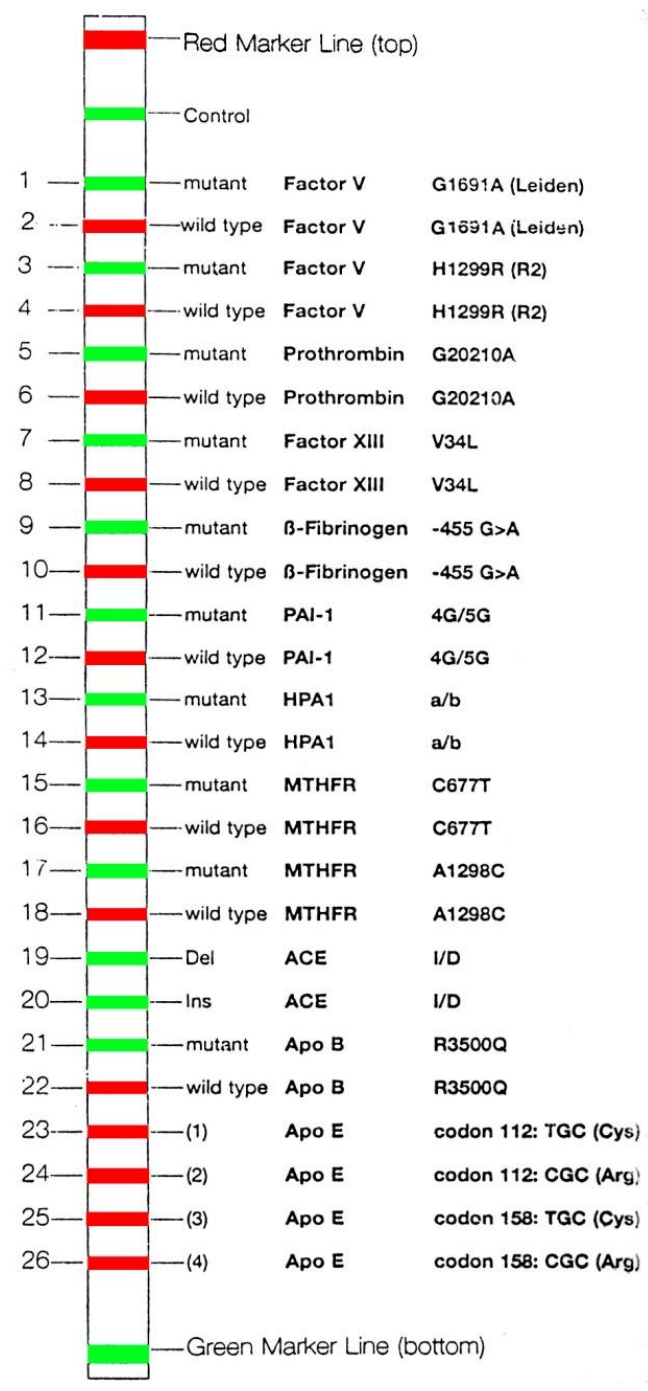

( Figure 1) CVD Strip 
Relationship between polymorphisms in thrombophilic

Table (1) Demographic and clinical characteristic of patient with preeclampsia and control group .

\begin{tabular}{|l|c|c|c|c|}
\hline & $\begin{array}{c}\text { Preeclampsia } \\
\text { group (N=15) }\end{array}$ & $\begin{array}{c}\text { Control group ( } \\
\mathrm{n}=10)\end{array}$ & P- value & Significance \\
\hline $\begin{array}{l}\text { Maternal age at } \\
\text { delivery (ys ) }\end{array}$ & $27.8 \pm 7.5$ & $27.3 \pm 7.2$ & 0.68 & $\mathrm{~N} \mathrm{~S}$ \\
\hline $\begin{array}{l}\text { Gestational age at } \\
\text { delivery (Wks) }\end{array}$ & $35.6 \pm 3.4$ & $38.3 \pm 3.4$ & $<0.001$ & $\mathrm{H} \mathrm{S}$ \\
\hline $\begin{array}{l}\text { Family history of } \\
\text { PE }\end{array}$ & $37.7 \%$ & $20.8 \%$ & 0.03 & $\mathrm{~S}$ \\
\hline BMI (kg/m) & $31.4 \pm 3.9$ & $27.9 \pm 4.6$ & $<0.001$ & $\mathrm{H} \mathrm{S}$ \\
\hline Parity & $2.4 \pm 1.7$ & $2.8 \pm 1.8$ & 0.18 & $\mathrm{~N} \mathrm{~S}$ \\
\hline
\end{tabular}

$\mathrm{NS}=$ non significant.

$\mathrm{H} \mathrm{S}=$ highly significant.

$\mathrm{S}=$ significant .

Table( 2) Frequency of thrombophilia genotypes in women with preeclampsia and control groups

\begin{tabular}{|l|c|c|c|c|}
\hline Thrombophilia genes & PE $(\mathrm{n}=15)$ & Normal $(\mathrm{n}=10)$ & $\mathrm{p}$ - value & Significant \\
\hline Factor V leiden & $2(15) 13 \%$ & $1(10) 10 \%$ & 0.506 & $\mathrm{NS}$ \\
\hline $\begin{array}{l}\text { Factor } \\
\text { II(20210) }\end{array}$ & $0(15) 0 \%$ & $0(10) 0 \%$ & - & - \\
\hline $\begin{array}{l}\text { B. Fibrinogen (455 } \\
\text { G/A) }\end{array}$ & $1(15) 6 \%$ & $1(10) 10 \%$ & 0.513 & NS \\
\hline Factor XIII (V34L) & $2(15) 13 \%$ & $1(10) 10 \%$ & 0.506 & NS \\
\hline $\begin{array}{l}\text { Plasminogen } \\
\text { Activator Inhibitor -1 }\end{array}$ & $9(15) 60 \%$ & $0(10) 0 \%$ & 0.000 & HS \\
\hline MTHFR (c677t) & $3(15) 20 \%$ & $2(10) 20 \%$ & - & \\
\hline MTHFR (A1298c) & $0(15) 0 \%$ & $0(10) 0 \%$ & - & \\
\hline ACE I/D & $0(15) 0 \%$ & $0(10) 0 \%$ & - & NS \\
\hline APO B gene & $2(15) 13 \%$ & $1(10) 10 \%$ & 0.506 & - \\
\hline APO E gene & $0(15) 0 \%$ & $0(10) 0 \%$ & & \\
\hline
\end{tabular}

$\mathrm{N} \mathrm{S}=$ non significant .

$\mathrm{H} \mathrm{S}=$ highly significant.

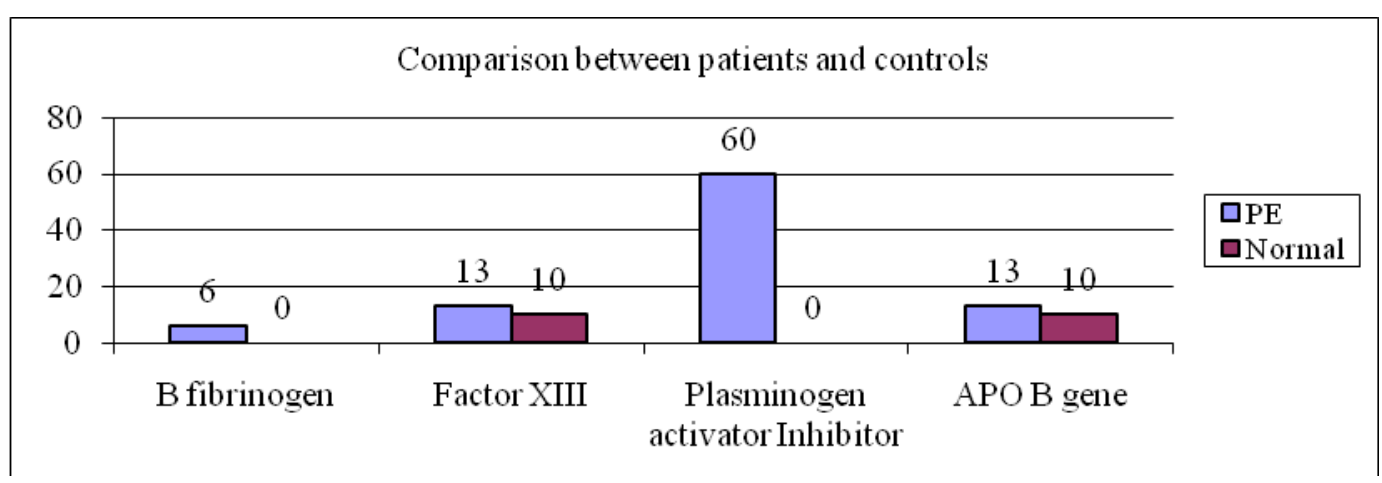

Figure (2 ): Comparison between patients and control as regard thrombophilic gene. 


\section{Discussion}

Several functional genes in the coagulation system may contribute to an increased risk of thrombotic events that may result in preeclampsia. A number of case-control studies of affected and unaffected mothers indicate such associations ( 11$)$, but this relationship is still disputed (12).

Thrombphilias have been associated with preeclampsia in a number of studies . They may contribute to the uteroplacental thrombosis that is frequently seen in preeclampsia . The relation of $4 \mathrm{G} / 5 \mathrm{G}$ to preeclampsia has been investigated in some previous studies .However the correlation between PAI-1 4G/ 5G polymorphism and preeclampsia is still controversial (13).

In our study, the prevalence of heterogeneous PAI 4G/5G was significantly higher in preeclampsia group as compared to normal control group. Wherease, no significant differences have been noticed between patient and control groups as regard factor $\mathrm{V}$ leiden, factor II, factor XIII , B-fibrinogen, M T H R , A C E and ApoB and $\mathrm{E}$ gene. PAI-1 is an important inhibtor of the fibrinolysis,so increasing transcription rates of plasminogen activator inhibitor result in an increase risk of thrombosis.

The relationship between polymorphisms in thrombophilic genes and preeclampsia were studied in different populations with variable results. Our findings were similar to what has previously been described in Thailand and European populations,some authors perform a summarative analysis on recent previous results on $\mathrm{PAI}-$ 4G/5G polymorphism as a risk factor of preeclampsia. According to this analysis, the authors proposed that the pattern of PAI - 4G/5G polymorphism might represent a useful marker of increased risk for preeclampsia ( 8 ).

Also, in agreement with our findings, Yosef et al showed the essential role of plasminogen activators and plasminogen activators inhibitors in maintainance of fibrinogenic and fibrinolytic balance. Moreover,Choi and Pai suggested the role of tissue plasminogen activators and plasminogen activators inhibitors in the prevention of hypertensive disorders in pregnancy.

In contrast to our data, Brazilian researchers concluded that the presence of one genotype risk factor alone does not seem to be associated with preeclampsia. However interactions among more than one genotype risk factors have a role in the development of the preeclampsia ( $9-16$ ).

Also,some Saudi researches reported that Anti thrombin III ,protein C deficiency and hyperhomocystienemia were associated with pregnancy induced hypertension (PIH) but FV lieden and prothrombin 20210 mutations were not found to be related to PIH (17).

On the other hand, other Saudi researchers reported that no difference between preeclamptic patients and normal control as regarde thrombophilic genes mutations and suggested that the preeclamptic patients should not be tested for thrombophillia (18).

To asses the relationship between thrombophilic mutations and the risk of preeclampsia in England populations ,a metaanalysis was performed on number of studies and showed an association between factor $\mathrm{V}$ leiden and preeclampsia. Moreover, Deuch researchers reported that hereditary thrombophilic disorders were associated with fetal growth restriction but not with maternal hypertensive disorders , suggesting their effect on placental function ( 19 -13)

Also, in study on Greek population, the association between combined inherited thrombophilia and adverse pregnancy outcome in the South-Western Greek population was investigated . Three hundred and ninety-six healthy Greek women with spontaneous pregnancies were tested for combinations of the three commonest thrombophilic mutations (Factor II G20210A, Factor V Leiden and MTHFR C677T) and followed for adverse pregnancy outcomes. Statistical analysis revealed that the presence of FV Leiden/MTHFR T677T double genotype 
increases the risk for placental abruption . $(7,20)$

Our report added weight to the possible interaction among polymorphism in PAI and others due to high prevlance of combined thrombophilia(more than one risk factors) in patients with severe preeclampsia as compared to mild preeclampsia. These results were consistent with findings in Brazilian populations. Therefore ,these discrepant results may be related to the genetic differences between different populations.

In conclusion we noticed increasing frequency of interaction of PAI-1 gene and other thrombophilic genes in cases of severe preeclampsia. Therefore, we suggest that the pattern of PAI 4G/5G polymorphism might represent a useful marker of increased risk of preeclampsia in our region.

\section{References}

1. Hladunewich $\mathbf{M}$, Karutnanchi $\mathbf{S}$ and Lafayette $R$ (2007): In depth review: pathophysiology and clinical manifestations of preeclampsia. CJASN., (2): 543-549.

2. Sibai B, Dekker $G$ and Kupfermine $M$ (2005): Preeclampsia. Lancet, 365:785799.

3. Laivuori H (2007): Genetic aspects of preeclampsia. Front Biosci (12) : 2372-82.

4. Paidas MJ, Ku DH, Arkel YS (2004): Screening and management of inherited thrombophilias in the setting of adverse pregnancy outcome. Clin Perinatol., 31: 783-805.

5. Bogdanova N, Markoff A (2008): Genetic Predispositions to Thrombophilia Associated with Recurrent Pregnancy Loss J. Reproduktionsmed. Endokrinol.,5 (2), 101-105.

6. Hosseini MS, Gharehkhan P, Sadeghi M (2007): Association of inherited thrombophilia and antiphospholipid syndrome with severe preeclampsia Iranian Journal of Reproductive Medicin, (4) : 183-186,

7. Karakantza M, Androutsopoulos G, Mougiou A, Sakellaropoulos G, Kourounis G, Decavalas G (2008): Inheritance and perinatal consequences of inherited thrombophilia in Greece. Int $\mathbf{J}$ Gynaecol Obstet., 100(2):124-9.

8. Wiwanitkit $\mathbf{v}$ (2006): Correlation between plasminogen activator inhibitor-1 4G/5G polymorphism and pre-eclampsia: an appraisal, Arch Gynecol Obstet., 273(6):322-4.

9. Robertson $\mathbf{L}, \mathbf{W u}$ O, Langhorne $\mathbf{P}$ (2006): Thrombophilia in pregnancy: a systematic review, Br. J. Haematol., 132: 171-196.

10. American College of Obstetricians and Gynecologists (2002). Diagnosis and management of preeclampsia, ACOG Pract. Bull., 33 :1-14.

11. Morrison ER, Miedzybrodzka AZ, Campbell DM (2002;): Prothrombotic genotypes are not associated with preeclampsia and gestational hypertension: results from a large population-based study and systematic review, Thromb. Haemost., 87:779-785.

12. Kujovich JL (2004): Thrombophilia and pregnancy complications, Am. J. Obstet. Gynecol., 191 : 412-424.

13. Ganzevoort W, Rep A, De vries J (2007): Relationship between thromophilic disorder and type of severe early -onset hypertensive disorder of pregnancy , Hypertensve Pregnancy .,26 (4): 433- 45.

14. Yosef S, Malgorzata P, Maciej S ( 2005): Expression of urokinase plasminogen activator, its receptor and plasminogen activator inhibitor in the plasma of pathological pregnancy women. The Internal Journal of Obstetric and Gynecology , 5 ( 1) : 6-9

15- Choi JW, Pai SH (2002): Tissue plasminogen activator levels change with plasma fibrinogen concentrations during pregnancy. Ann Hematol., 81: 611-615.

15. Dalmáz CA , Santos KG, Botton MR, Tedoldi CL, Roisenberg I (2006): Relationship between polymorphisms in thrombophilic genes and preeclampsia in a Brazilian population Blood Cells, Molecules, and Diseases, 37: 107-110.

17 Demir SC, Evroke C, Ozgunen T (2006): The relationship between pregnancy induced hypertension and congenital thrombophilia , Saudi Med J., 27 ( 8 ) : $1161-6$

18 Yalinkaya A, Erdemoglo M, Akdeniz N (2006): The relationship between thrombophilic mutations and preeclampsia : aprospectin case - control study . Ann Saudi MeD ., 26 (2 ) : $105-9$.

19 Lin J and August P (2005): Genetic thrombophilias and preeclampsia : meta amalysis , obstet Gynecol., 105 (1): 182 -92

20 Androutsopoulos G, Mougiou A, Karakantza $M$ et al (2007): Combined inherited thrombophilia and adverse pregnancy outcome, Clin Exp Obstet Gynecol .,34(4):236-8. 


\section{العلاقه بين هيئات الجينات المساعده على التغير وتسمم الحمل فى المي مجموعه من السيدات المصريات المئات}

*نهلة محمد عبد العزيز ـ **أمال حسين أبو سيف ـ *فوزيه عبد السميع الششتاوى *قمم الباثولوجيا الإكلينيكية ــ **قتم النساء و التوليا

إمر اض ارتفاع ضغط الدم تعد من الأسباب الرئيسية في حدوث وفيات في الأمهات

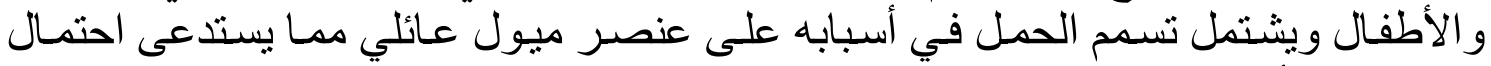

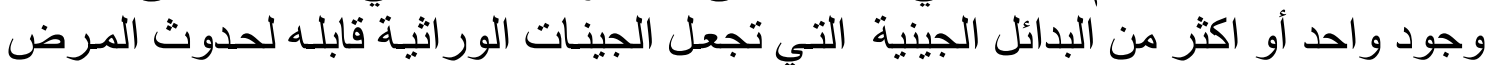
وبعض العائلات ربما يكون لديها ميول خاصئ التئل اللتحور الور اثئي.

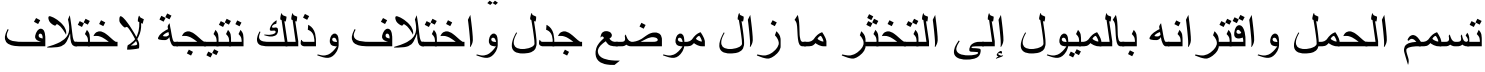
نتائج الدر اسات وتهدف هذه الدراسـة إلى تحديد العلاقـة مـا بين الميول للتختر وحدوث تسسم الحمل في السيدات المصريات تُم مقارنة عدد خمسة عشره سيدة تعانين من تسمم الحمل و عشر سيدات أخريات طبيعيات كمجمو عه ضابطه. ومن ثم نم اختبار جميع السيدات لتحور معامل خمسه ليدن و المعامل الثاني و المعامل الثالث

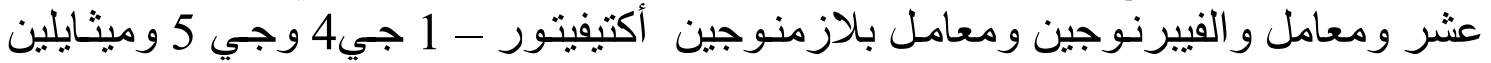

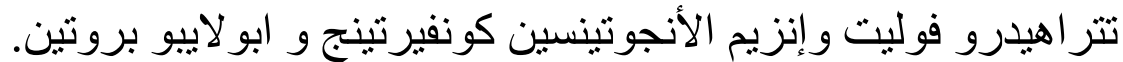

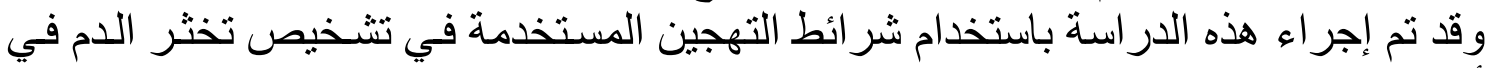

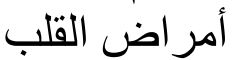
وكانت النتائج كالاتى النى النتائج

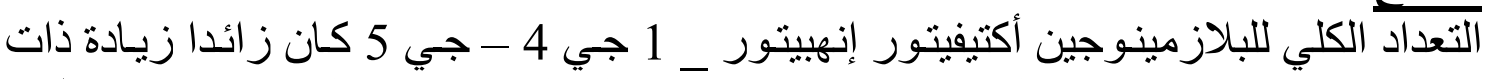

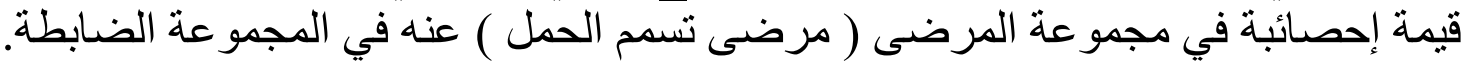

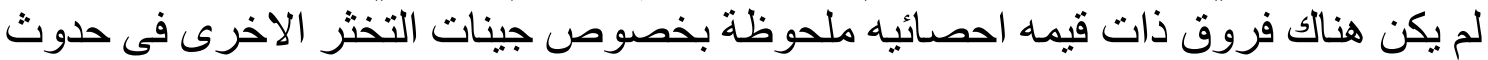

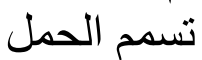

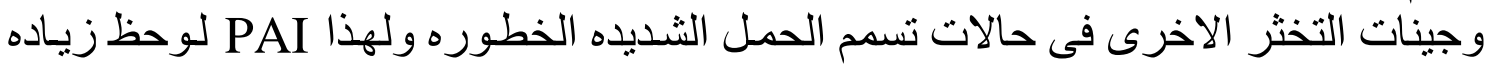

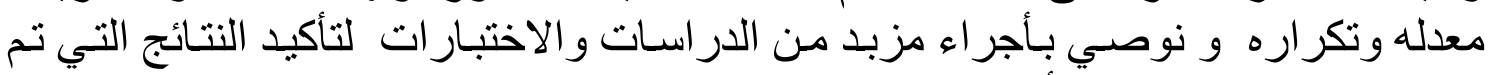

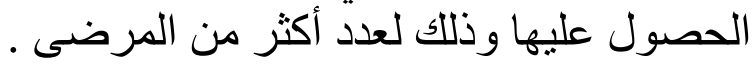

